\title{
NYILVÁNOSSÁG ÉS RÉSZVÉTEL A TELEPÜLÉSTERVEZÉSI FOLYAMATBAN ${ }^{1}$
}

\author{
(Participation in Urban Planning)
}

\section{CSANÁDI GÁBOR - CSIZMADY ADRIENNE - KÖSZEGHY LEA}

Kulcsszavak:

városszociológia várostervezés településtervezés participáció

A városfejlódés hátterében egyrészt a piacgazdaság által generált spontán folyamatok allnak, másrésżt várospolitikai-várostervezési folyamatok. Ez utóbbi folyamatok következményeként egyes társadalmi csoportok elönyösebb, mások hátrányosabb helyzetbe kerillhetnek. Amikor várostervezési, várospolitikai döntések szociológiai elemzéséröl gondolkozunk, nem csupán - sokszor talán nem is elsösorban - a konkrét fizikai valójában is megjelenö eredmény az, amelyet szemügyre veszïnk, hanem az e mögött meghúzódó nyllt, vagy rejtett társadalmi érdekek, hatalmi viszonyok, konfliktusok rendszere elemzésünk tárgya (hogyan függenek össze a külsö érdekek és hatalmak küzdelmeivel, mennyiben képes autonóm müködêsre, saját ethosának a képviseletére, mikor és mennyiben szolgálója, illetve kiszolgálója a körülötte müködó erösebb érdekviszonyoknak.) E bonyolult kérdéskör részletes kifejtését - amelyet az egyszerüség kedveért a várostervezés szociológiájának is nevezhetünk - ebben a tanulmányban a nyilvánosság és részvétel vizsgálatával kezdjük.

\section{Bevezetés}

Hosszú idő óta nagy viták folynak arról, hogy a várostervezésben érintett területek lakóinak milyen szintủ és módszerủ részvétele szükséges (célszerü, helyes stb.) magában a tervezési folyamatban. Szociológiailag igen érdekes kérdés, hogy a döntéshozás és az ehhez szükséges szakmai elökészító tevékenységek között miért éppen ez az, ahol a lakossági részvételrỏl, annak szükségességérỏl és mikéntjéról egyáltalán vita folyik. Hiszen a településtervezés folyamán - sok más települési szintü döntéshez hasonlóan - forrásokat kell egy meghatározott módon elosztani, melynek következményeképpen a döntések a lakosság bizonyos csoportjait előnyỏsen, másokat hátrányosan érintenek. E döntések a településtervezési döntésekhez hasonlóan általános elvek, elözetes dỏntések alapján szakértői előkészítést igényelnek, tehát a konkrét részletektől eltekintve a településtervezés nem is különbözik olyan nagyon egy helyi önkormányzat más típusú, alapvetỏen a képviseleti demokrácia keretei között megszülető lényeges döntéseitől (pl. költségvetés elosztása, egészségügyet támogassuk-e, vagy az iskolaügyet; szociális segélyt adjunk-e, vagy vállalkozásokat támogassunk stb.). A településtervezés lényegében csak abban különbözik ezektől, hogy a térbeli-fizikai környezet megváltoztatásával foglalkozik, de ez önmagában 
még nem indokolná azt, hogy a lakossági részvételnek itt nagyobb szerepet kellene adni, mint más területeken. Ezért a lakossági részvétel valószínủleg elvileg nem a várostervezés ügye, hanem a hatalom gyakorlásának és ellenőrzésének általánosan vizsgált, vizsgálandó kérdése. A szűkebb témánkban a várostervezés és az urbanisztikai problémák terén éppen azt lehet mondani, hogy a felmerüló kérdések szociológiai értelemben azért lényegesek, mert a várossal kapcsolatos problémák úgy tekinthetők, mint a társadalom alapstruktúráit, alapmechanizmusait érintő kérdések példái, konkrét területen való megjelenései. Nem véletlen például, hogy Peter Hall a Garden City mozgalom és a klasszikus anarchista társadalomkoncepciók közötti szoros kapcsolatra ilyen jelentős hangsúlyt helyezett (Hall 1996; 2000). Az ,anarchista” ebben a vonatkozásban a központi, elkülönült hatalom szerepével való szembehelyezkedés hangsúlyozását, a közvetlen, az érdekeltek számára áttekinthetỏ méretủ társadalmi egységekben való gondolkodást, döntéshozatalt stb. jelenti. Vagy ugyanő Le Corbusier koncepcióját a paternalista, központilag irányított társadalomeszmével hozza összefüggésbe stb. (Athéni Charta 1979). Éppen ezért a továbbiakban, amikor a várostervezésben való lakossági részvétel problémáiról beszélünk, akkor - hasonlóan más szociológiai elemzésekhez - a társadalom mủködésének egy meghatározott részterületén az általános strukturális vonásokat, múködési mechanizmusokat vizsgáljuk. Más szóval: szociológiai értelemben tesszük vizsgálatunk tárgyává a várostervezést, annak egy aspektusát (és nem „egyszerűen” a várostervezés tényleges müködésének hatékonyabbá, demokratikusabbá stb. alakítása a célunk, bár az sem kicsiny és egyszerủ feladat). Röviden, a tervezés szociológiai elemzése egyfelöl azzal foglalkozik, hogy a tervezés folyamataiban felmutassa a társadalom általánosan érvényesülő törvényszerüségeit, másfelől pedig bemutassa azt, hogy e szabályszerüségek milyen, a társadalom speciális területéböl adódó (vagyis itt a tervezési folyamattal összefüggő) speciális körülmények között érvényesülnek.

\section{Néhány participációs modell}

A településtervezésben való participáció kérdése ${ }^{2}$ mint téma már a 20. század elején felmerült az urbanisztikai gondolkodás történetében, elsőként Patrick Geddes vetette fel (Geddes 1915 [2000]). Később a modernista tervezéselmélet és a második világháború utáni tervezési gyakorlat korszakában évtizedekre háttérbe szorult. Az 1960-as években a háború utáni nagy városépítési akciók és az alapjukat adó tervezéselmélet kritikája kapcsán, illetve a nyugat-európai és amerikai társadalmak hatvanas évekbeli társadalmi kríziseinek hatására merült fel újra, mind az építészek, várostervezők részéről, tehát „,felülről”, mind a lakossági tiltakozások kapcsán „alulról” (Fogarasi 1995). A neokonzervatív rezsimek idején, a tervezés helyzetének a hetvenes években bekövetkezett változásai nyomán sok esetben ismét csökkentek a lakossági részvétel lehetőségei (Jacobs-Appleyard 2000). A kortárs tervezéselméletekben a hatvanas évek hagyományai és a válság nyomán elfogadottá vált 
Csanádi Gábor - Csizmady Adrienne - Köszeghy Lea : Nyilvánosság és részvétel a településtervezési folyamatban. - Tér és Társadalom 24. évf. 2010/1. 15-36. p.

TÉT XXIV. évf. 2010 - 1

Nyilvánosság és részvétel a ...

a lakossági részvétel szükségessége; ma már aligha találni olyan szakirodalmi forrást, amelyik ne kezelné magától értetődően fontos kérdésnek.

A lakossági részvételre vonatkozóan többféle (nagyrészt induktív módon megalkotott) elmélet született az elmúlt évtizedekben. Közülük talán a leghíresebb Sherry Arnstein 1968-ban közzétett modellje, a lakossági részvétel „éérája”. Arnstein a lakossági részvétel legfontosabb elemének a hatalom újraelosztását, a társadalmi előnyök és hátrányok elosztását meghatározó döntésekben való részvételt tartja; minden olyan modell, amelyben ez nem történik meg, véleménye szerint formális, üres, a hatalomnélküliek számára frusztráló folyamat (Arnstein 2000).

A lakossági részvétel lehetséges módjait egy (egydimenziós) létrával ábrázolja, amelynek saját meghatározása szerint voltaképpen csak a legfelső három szintje jelenti a valódi lakossági részvételt, az ez alatti szintek annak csak valamilyen formális modelljét mutatják, ám ez utóbbiak között is többféle módon alakulhat a lakosság megjelenése a tervezési folyamatban (1. táblázat).

\section{TÁBLÁZAT \\ Az Arnstein-féle lakossági részvétel létrája \\ (Arsteni's Ladder of Citizen Participation)}

8. közösségi irányítás

7. átruházott hatalmi funkciók

6. partnerkapcsolat

5. megbékítés, kiengesztelés

4. konzultáció

3. információ

2. terápia

1. manipuláció a közösségi hatalom fokozatai (irányítás lehetséges)

a jelképesség fokozatai (befolyásolás lehetséges)

a részvétel hiánya (befolyásolás nem lehetséges)

Forrás: Lukovich (1997).

A manipuláció esetében nincsen lehetőség a részvételre, a döntések befolyásolására, ám rendszerint van valamilyen testület, amelyben lakossági képviselők is részt vesznek, de valódi befolyásolási képesség nélkül, tehát „rábólinthatnak” a tervre, ezáltal legitimálva a tervezési döntéseket. Arnstein nem is ezt a fokozatot utasítja el a leginkább, hanem a következő fokozatot, tehát a terápiát, ez ugyanis „őszintétlen és arrogáns" (Arnstein 2000, 245). ${ }^{3}$

A következő fokozatok esetében már lehetséges a döntések valamilyen mértékü befolyásolása. Lukovich Tamás Arnstein modelljét elemezve ehhez azt teszi hozzá, hogy itt oly módon van lehetőség a lakossági vélemények döntésekbe való beépítésébe, hogy az még a hatalmi struktúra jelentős átrendeződése nélkül megoldható (Lukovich 1997). Az informálás egyirányú információáramlást, a lakosság tájékoztatását jelenti, a konzultáció már nem egyirányú információáramlás, itt már a lakosságnak is lehetősége van észrevételeit megtenni (kérdőíves felmérések, megbeszélések, lakossági fórumok), azonban nincsen biztosíték arra, hogy ezeket a döntés során figyelembe is veszik. A megbékítés, kiengesztelés esetében a lakosság javaslatokat 
tehet, de figyelembevételük a hatalom mérlegelésén múlik - a legtöbb Arnstein által elemzett program legfeljebb erre a szintre jutott el (Arnstein 2000, 247). Tapasztalatai szerint e szint tipikus problémája volt egyebek mellett az, hogy a döntéshozók nem beszélték meg a részvételre vonatkozó elvárásokat a lakossággal, a bevont lakosok nem voltak tisztában jogaikkal, felelősségeikkel, lehetőségeikkel, a lakosság bizalmatlan volt a programok iránt, a bevont lakossági csoportok általában nem reprezentálták a lakók összességét, csak azok dinamikusabb csoportjait, a lakosság számára nyújtott információ kevés volt, a hatalom nem volt nyitott új megoldásokra.

A felső három fokozatban van jelen a tulajdonképpeni hatalommegosztás. Lukovich Tamás megállapítása szerint ezek a fokozatok már a hatalmi struktúra forradalmi átalakításával járnak. A partnerkapcsolat esetében tárgyalások folynak a hatalommal, alkuk köttetnek, megosztják a tervezés és a döntéshozatal felelösségét. A döntéshozatalban - hiszen a jogszabályok szerint választott testület feladata nem vehettek részt a lakossági csoportok, de ebben a fokozatban el tudták érni, hogy az ö preferenciáiknak megfelelően szülessen a döntés. A delegált hatalomnál már döntéshozó jogkör (pl. vétójog) van „leadva” a lakossági csoportoknak, bár a végső döntést itt is választott szerv hozza. A legfelső szint a teljes irányító hatalom, teljes felelősség valamely dolog (pl. a helyi iskola) irányításáért.

Arnstein modelljét később sokan kritizálták, noha ő maga is felhívta a figyelmet a modell néhány korlátjára - olyanokra is, amelyek később a kritikákban szerepeltek: 1) nem foglalkozik a lakossági részvételt hátráltató tényezőkkel, így a hatalom részéről a hajlandóság, a lakosság részéröl a képesség hiányával; 2) bár a modellből úgy tünik, hogy a „hatalom”, illetve a „lakosság” oldalát homogénnek feltételezi, ez természetesen nem így van, különféle nézőpontok, hasadások, érdekütközések, alcsoportok vannak mindkét oldalon; 3) a modell figyelmen kívül hagyja a szereplök korlátait: az egyik oldalon a paternalista hajlamú kormányzatot, amely jogot formál az uralkodásra, a másik oldalon a részvételre aspirálók elégtelen ismereteit, szerveződő-képességét; 4) a több hatalom nem feltétlenül jelent jobbat, hiszen igazságtalanabb és egyenlötlenebb helyzeteket teremthet (Lukovich 1997); 5) az Arnstein által vázolt participáció egy új helyi elitet képezhet, a lakosság azon részét, akik beleszólhatnak a döntésekbe (Potapchuk 1995).

A döntéshozatalban való lakossági részvétel egyébiránt egy további fontos kérdést vet fel, a legitimáció kérdését - ezt azért célszerü itt kiemelni, mert számos hazai empirikus kutatásban is felmerülö téma, hogy a képviseleti demokrácia kereteit „feszegető" közvetlen részvétel, a részt vevő lakossági csoportok, civil szervezetek milyen legitimációval bírnak, kit képviselnek, milyen alapon hallatják a hangjukat egy-egy döntés kapcsán.

Arnsteinre reflektálva azóta számos lakossági részvételre vonatkozó modell született (pl. Potapchuk 1995), e helyen közülük egyet tartunk fontosnak röviden bemutatni: Karl Maiernek a rendszerváltás utáni cseh tervezési gyakorlatra épülỏ modelljét (Maier 2001).

Maier (2001) a kortárs cseh várostervezés gyakorlatát vizsgálva arra a következtetésre jutott, hogy a lakossági részvétel modellje nem egy egydimenziós létraként 
Csanádi Gábor - Csizmady Adrienne - Kőszeghy Lea : Nyilvánosság és részvétel a településtervezési folyamatban. - Tér és Társadalom 24. évf. 2010/1. 15-36. p.

képzelhető el, nem Arnstein tipológiájának megfelelően, hanem inkább koncentrikus, táguló körökben, melyek közepén a hatalmi központ található, körülötte pedig táguló körökben az érdekcsoportok, érdekhordozók. A hatalmi központ körül találhatók a partnerek, a következő körben a tanácsadók és az ,intézményesített” ellenzők, majd a küzdő ellenzők és tiltakozók, a következö körben az informált, de nem feltétlenül meghallgatott csoportok, mindezeken kívül pedig a csendes többség. $\mathrm{Az}$ érdekhordozó és a hatalmi központ kapcsolata több arnsteini létrafokot is érinthet. Az előbbi elöször legitimitásért küzdő tiltakozó, majd ha sikeres, elfogadják mint ,rendes", legitim tiltakozót, a további tervekben a hatalom keresi vele a konszenzust. A következő lépésekben esetleg alternatív terveket, koncepciókat dolgoz $\mathrm{ki}$, végül bekerül a fóvonalbeli tervezésbe és a hatalmi centrum része lesz. A rendszer összességében dinamikus egyensúlyban van.

$\mathrm{Az}$ 1. ábrân a hatalmi központ és az azzal különféle viszonyban lévő érdekhordozók fent ismertetett legkomplexebb rendszere látszik, amely Maier elképzelései szerint a demokratikus viszonyok között jellemző.

\section{1. ÁBRA}

Maier modellje a hatalom és a különféle érdekhordozók komplex kapcsolatairól a demokratikus rendszerben (Maier's Model of Citizens Participation)

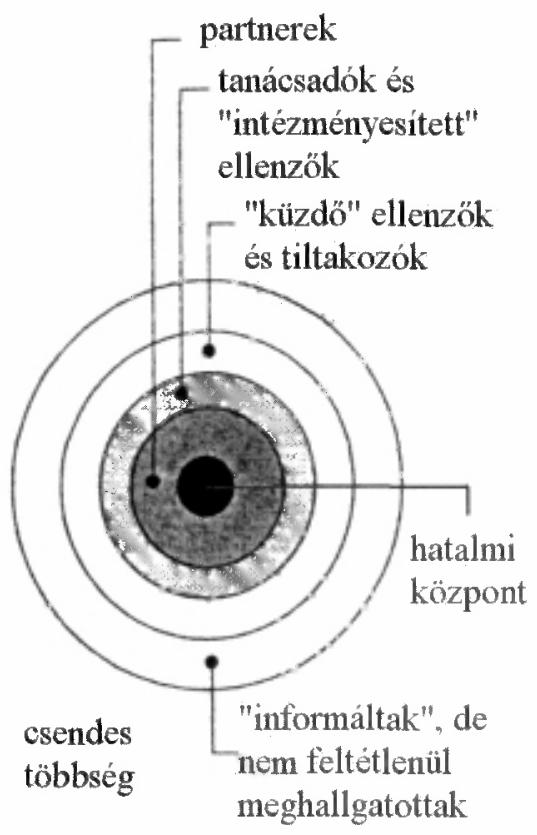

Forrás: Maier (2001). 
Csanádi Gábor - Csizmady Adrienne - Köszeghy Lea : Nyilvánosság és részvétel a

településtervezési folyamatban. - Tér és Társadalom 24. évf. 2010/1. 15-36. p.

A modellt tehát „,keresztmetszetszerüen” (vagyis nem az egyes csoportok ,karrierje”, hanem egy adott pillanatban a rendszer egésze felől) nézve a különféle érdekhordozók különféle „távolságra” lehetnek a központi hatalomtól, tehát a modell nem „az" érdekhordozókról beszél, hanem azok plurális és a hatalommal változatos kapcsolatban lévő világát feltételezi. E csoportok döntéshozatali folyamatokra gyakorolt hatása eltérö lehet, akár egy-egy döntéshozatali folyamatban is eltérö elemek jelenhetnek meg. Modelljében Maier ugyanakkor arra is utal, hogy a hatalmi központ körül megjelenő érdekhordozók nem feltétlenül jelentik a társadalom többségét, még csak nem is feltétlenül reprezentatívak. Egy-egy csoport felöl nézve pedig a modell a korábbiaknál finomabban képes annak a hatalmi központhoz való viszonyát és - ez a korábbi modellekhez képest szintén újdonság - annak változását megjeleníteni, sőt e modellben akár olyan helyzet is elképzelhető, hogy egy csoport különféle helyzetekben, illetve helyeken eltérö kapcsolatban legyen a hatalmi centrummal. Tehát az egyes szervezetek maguk is követhetnek valamiféle stratégiát a hatalmi központtal való kapcsolatuk alakításakor.

A lakossági részvétellel kapcsolatban számos további, modellszinten is fontos kérdés vethetö fel; közülük érdemes kiemelni a bevont népesség társadalmi összetételének kérdését (lásd pl. Lukovich 1997), illetve azt a tényt, hogy a modellek többsége kimondva vagy kimondatlanul normatív, a mind nagyobb mértékü társadalmi részvételt tekinti elérendő célnak. Ezzel összefüggésben a részvétel előnyeit emeli ki, miközben akár deduktív, akár induktív megközelítésben a részvétel számos lehetséges problémája is felsorolható (lásd pl. Lukovich 1992). A részvétel elönyei: hozzájárulhat a demokratikus légkör, egy jobb minőségủ politikai élet kialakulásához, a bürokratikus apparátus kontrolljához, érzékenyebbé teheti azt a különféle társadalmi csoportok problémái, igényei iránt, friss elképzeléseket hozhat a tervezésbe, csökkentheti a későbbi konfliktusok számát, megfelelöen kezelve általánosságban is a konfliktusfeloldás, a közösségi érzés kialakításának jó eszköze lehet. Hátrányai: nőhet a hatalmi konfliktusok száma, több időt és több pénzt igényel (bár ha tekintetbe vesszük az elmaradó participáció után később felmerült konfliktusok „erőforrásrabló” hatását, összességében ez nem biztos), parciális érdekek érvényesítéséhez vezethet, a kizárás eszközévé válhat (amennyiben bizonyos, több erőforrással rendelkező csoportok „,bekerülnek", mások pedig kimaradnak a döntés-elökészítésböl).

\section{Kontextusfüggöség}

A tervezés és a participáció kapcsolatának kérdésében egyébként Amerika és Európa nagyban különbözik. Az amerikai kultúrában ugyanis evidencia, hogy az érdekeltek - esetleg szövetkezve a környezetükben lakókkal - önállóan oldják meg problémáikat. Létrehozzák saját szervezeteiket, képviselik a saját érdekeiket, és kevésbé támaszkodnak a központi intézményrendszerre és a hatalomra. Az európai országokban nincs hagyománya ilyen típusú kultúrának, és ebből következően Nyugat-Európában is sok tekintetben másképpen vetődtek fel a participációt érintő 
Csanádi Gábor - Csizmady Adrienne - Köszeghy Lea : Nyilvánosság és részvétel a településtervezési folyamatban. - Tér és Társadalom 24. évf. 2010/1. 15-36. p.

kérdések, mint az amerikai kontinensen. Jóllehet a nyugat-európai országokban az utóbbi harminc évben a participáció eléggé megerősödött, mégis úgy tủnik: a történelmi kontextusok mintha fontosabbak lennének, mint azt gyakran feltételezik. Úgy is fogalmazhatunk, hogy a városfejlődés neoweberianus, történeti megközelítése mely sok esetben minőségileg is eltérő fejlődési utakat képzel el - jobb paradigmának látszik a participációs folyamatok sajátosságainak megértésében, mint az „ökológiai" - az azonos ösvényen egymás után haladó társadalmak modelljével dolgozó - városfejlődési paradigma. Ebből az is következik, hogy bár az amerikai megközelítések sok tekintetben tanulságosak, témánk szempontjából az európai gyakorlat és ennek értelmezései relevánsabbak. Peter Hall (1996) megjegyzése például, miszerint a várostervezésnek a garden city típusú mozgalmai egyenesen az anarchista társadalomfelfogással összekapcsolódó koncepciók voltak, azt mutatja, hogy hasonlóan az anarchizmus központi hatalmat támadó, kétségbevonó koncepciójához - a városfejlesztési ideákban léteztek olyan, a gyakorlatba is átvitt elképzelések, amelyeknek a lényegét az önálló, komplex, a „külvilágtól”, tehát a központi hatalmaktól nem függó entitások jelentették. Ráadásul ezek a települések éppen azért látszottak elképzelőik szemében ideálisnak, mert méretükből, struktúrájukból következően ügyeiket a lakói még át tudják látni, és ezért képesek az irányítással kapcsolatos problémák kezelésére is. A participáció értelmezését e gondolatoknak is megfelelően éppen a hatalmi dimenzió bevonásával lehet tovább bővíteni. Az ugyanis, hogy a különböző csoportok érdekképviseleti, érdekérvényesítési mechanizmusai hogyan müködnek, valószínủleg a hatalom müködési módjának összefüggéseiből érthetô meg. A kelet-közép-európai erősen központosított, paternalista rendszerekben - mint amilyennek a szocializmus is számít - lényegileg hiányzik a spontán érdekképviseleti csoportok létrehozásának és intézményesitésének kulturrája, illetve annak gyakorlata, hogy hogyan lehet a bürokratikus hatalmi struktúrával szemben bizonyos kérdésekben befolyást szerezni. Ennek következtében esetünkben nem egyszerủen az a kérdés, hogy például a különböző „grass root" mozgalmak egymás közötti konfliktusai, intézményesülési nehézségei és a „,hivatalos” hatalomgyakorlókkal vagy a professzionális tervezökkel való kapcsolataik milyen technikai problémákat vetnek fel. Ebben az esetben azzal a mélyebb problémával kell megküzdeni, hogy ilyen mozgalmaknak milyen helyzetük lehet az adott döntési struktúrában, mennyiben artikulálnak meghatározott (esetleg új, korábban nem képviselt) érdekeket, vagy mennyiben jelentik pusztán a hatalom függelékeiként az amúgy is kiváltságos helyzetủek előnyeinek biztosítását, megerősítését.

A kelet-közép-európai volt szocialista országokban éppen a történelmi tradíciókból fakadóan a helyi önkormányzatok képviseleti módon történő múködtetése is meglehetősen nagy változás a korábbi patriarchális, központi döntéshozatallal szemben. A várostervezés vonatkozásában e változás kétségtelen elönye, hogy a döntések közelebb kerülnek ahhoz a területhez, amelyet hatásaik érintenek, ugyanakkor önmagában nem nyilvánvaló, hogy az adott területen érvényesiiló érdekkonfliktusok megoldásának milyen mechanizmusai alakulnak ki. A központi direktíváktól való függetlenség igénye és a vágy arra, hogy egy központi döntéshozó 
Csanádi Gábor - Csizmady Adrienne - Kőszeghy Lea : Nyilvánosság és részvétel a

településtervezési folyamatban. - Tér és Társadalom 24. évf. 2010/1. 15-36. p.

22 Csanádi G.-Csizmady A.-Köszeghy L.

TÉT XXIV. évf. 2010 1

szerv segítsen megtalálni a helyes utat, nagyon gyakran együttesen jelentkezik a helyi döntési (várostervezési) mechanizmusokban. Ezt a képet bonyolítja a piaci érdekek megjelenésének sokirányú következményrendszere, valamint az, hogy a tervezéssel foglalkozók milyen módon illeszkednek be ebbe a rendszerbe. A tervezési munka folyamán a bonyolult viszonyrendszer kezelése - mint interjúinkból kitủnik - egyáltalán nem egyszerü folyamat. Az intézményi szereplök közötti kapcsolatok müködtetése a kulcspozícióban lévök sok energiáját emészti fel. A paternalista tradíciókból fakadóan ugyanakkor az is következik, hogy az önkormányzati szinten megszerzett hatalom gyakorlása során a ténylegesen érintettek és (civil)szervezeteik esetleges bevonása a munkába rendszerint nem tűnik sem természetesnek, sem célszerủnek, és legfeljebb a törvény formális elöírásai azok, amelyek a korábban említett példához hasonlóan itt is müködnek.

Magyarországon a rendszerváltás után - a helyi önkormányzatok szerepének törvénybe iktatásával - a központi döntéshozatal egyeduralkodó volta természetesen halványult. Ugyanakkor sok más egyéb terület mellett a várostervezés, városirányítás kérdésében is világossá vált, hogy a döntési szint lejjebb kerülése korántsem teszi a hatalommal rendelkezők számára nyilvánvalóvá, hogy a megszerzett döntéshozatali lehetőségekbe célszerü vagy szuikséges volna az érintettek szélesebb körét is bevonni. Általában is közismert - és empirikus kutatásunk adatai is jelzik -, hogy a lakossági meghallgatások és ehhez hasonló intézményes formák hasznát nagyon alacsonyra értékelik a helyi önkormányzatok tisztviselői. Nem kis részben ennek következménye az, hogy ezek valóban rossz hatékonysággal müködnek, és a lakosság véleménye sem pozitívabb róluk, mint a választott képviselöké.

\section{A településtervezés törvényi szabályozása}

A participációt az egyes nyugat-európai országokban eltérően szabályozzák, és a szabályok Európai Unión belüli egyesítése még nem került napirendre. Ugyanakkor nagy elörelépést jelentett 1998 júniusában az aarhusi egyezmény ${ }^{4}$, melyben témánk szempontjából három igen fontos pont is szerepel (Ongjerth 1999):

1) a polgároknak joguk van a környezetük állapotára vonatkozó adatok birtoklására;

2) joguk van megismerni a környezet alakítására vonatkozó közhatalmi döntéseket, és azok tartalmához javaslatokat tenni;

3) ha ezeket a hatóságok nem tartják tiszteletben, az érintettek bírósághoz fordulhatnak.

Az Európai Parlament törekvései alapján úgy látszik, hogy az egyezményben foglaltak betartása a későbbiekben feltétele lesz az EU-projektekhez való csatlakozásnak, illetve a támogatások megszerzésének. Mindezek miatt még inkább fontos Magyarország szempontjából a hazai gyakorlat megismerése és a lehetséges részvételi módozatok kidolgozása. 
Csanádi Gábor - Csizmady Adrienne - Köszeghy Lea : Nyilvánosság és részvétel a településtervezési folyamatban. - Tér és Társadalom 24. évf. 2010/1. 15-36. p.

Az egyezmény második pontjában foglaltaknak Magyarországon az épített környezetről szóló 1997. évi LXXVIII törvény ${ }^{5}$ (Étv.) 3. és 9. paragrafusa tesz eleget, melyek rögzítik a településfejlesztés során az egyủttmüködés követelményeit a rendezési tervezés vonatkozásában (a fejlesztési koncepciók kidolgozására nincs törvényben rögzített eljárásrend): Az Étv. 3. §-a szerint

„(...) az épített környezet alakítása és védelme során a közérdekü intézkedéseket és döntéseket megelözően, illetőleg azok végrehajtása során biztosítani kell a nyilvánosságot és a közösségi ellenőrzés lehetőségét (...). Gondoskodni kell az érdekelt állampolgárok, szervezetek megfelelő tájékoztatásáról, és lehetőséget kell adni részükre véleménynyilvánításra és javaslattételre." [Étv. 3. \& (2)]

A gyakorlatban két fontos ponton van lehetőség a lakosság részvételére a tervezési folyamatban. Az egyik ilyen pont a véleményezési eljárás:

„A helyi építési szabályzatot és a településrendezési terveket a megállapítás, illetve a jóváhagyás előtt a polgármesternek (főpolgármesternek) véleményeztetnie kell a külön jogszabályban meghatározott államigazgatási, az érintett települési önkormányzati és érdekképviseleti szervekkel, valamint társadalmi szervezetekkel, amelyek 45 napon belül adhatnak írásos véleményt." [Étv. 9. § (3)]

A másik pont a tervek jóváhagyás elötti közzététele:

„A véleményezési eljárás befejezése után a szabályzatot, illetőleg a terveket a megállapítás, illetve a jóváhagyás elött - azok magyarázatával együtt - a polgármesternek (fôpolgármesternek) legalább egy hónapra a helyben szokásos módon közzé kell tennie azzal, hogy az érintettek a közzététel ideje alatt azokkal kapcsolatban észrevételt tehetnek..." [Étv. 9. § (6)]

A törvény formálisan többé-kevésbé eleget tesz az aarhausi alapelveknek, gondoskodik a jogvédelemröl is, a jogok sérülésekor gyors és egyszerủsített hatósági eljárást ír elö, tehát elvileg talán jó keretet szolgáltathatna a részvételhez. A tekintetben, hogy ez ténylegesen mennyire járul hozzá a valódi, tartalmi részvételhez, feltehetỏen az a lényeges, hogy hatalmi pozícióban lévő alkalmazói-felhasználói mennyire tekintik olyan szabályozónak, amely tartalmi tevékenységüket meghatározza, és mennyiben olyan korlátnak, amelynek csupán formális figyelembe vétele a célszerủ. A másik oldalon ugyanígy kérdés, hogy azok, akiknek a megfelelö törvényhely lehetöségeket, jogokat biztosít, mennyire tudnak (és/vagy akarnak) élni ezekkel.

\section{A participáció gyakorlata: lakossági részvétel a bemutatott modellek tükrében}

A hazai gyakorlatot Arnstein modellje keretében értelmezve megállapítható, hogy a vizsgált esetek egyikében sem történt hatalommegosztás, tehát a hatalmi struktúra korábbiakhoz képest vett gyökeres átalakítása, a tervezés és a döntéshozatal felelösségének megosztása (bár utóbbi, mint láttuk, amúgy a legitimáció kérdését is felvetné). Arnstein modelljében a „legmagasabb fokra” a véleményezési eljárás kerülne, melynek során a civil szervezetek kritikát és javaslatokat fogalmazhatnak meg. Amennyiben pedig véleménykülönbség jelenik meg, a kötelezően összehívott 
Csanádi Gábor - Csizmady Adrienne - Köszeghy Lea : Nyilvánosság és részvétel a

településtervezési folyamatban. - Tér és Társadalom 24. évf. 2010/1. 15-36. p.

egyeztető tárgyaláson is kifejthetik gondolataikat, tehát az Arnstein által partnerségnek nevezett kapcsolattípus egyik eleme, a tervezési tevékenység megosztása megvalósulhat. A gyakorlatban azonban ennek kapcsán is alapvetően a tervezők és a foópítész határozzák meg, hogy mi az a javaslat, amit elfogadnak, és mi az, amit nem, tehát ilyen szempontból ez a bevonási forma inkább a megbékítés, kiengesztelés fokozatába sorolható. A lakossági fórumok gyakorlatuk alapján általában az Arnstein által leírt konzultáció fokozatába tartoznak, de egyes esetekben szerepük csak az információátadás, más esetekben pusztán formális, „kipipálható” tevékenységként szerepelnek a tervezési folyamatban, amely egyúttal legitimálja is a folyamatot. A közzététel, noha elvben lehetőséget biztosít észrevételek megtételére, a gyakorlatban inkább az informálás, tehát az egyoldalú információáramlás színtere. Ugyanakkor a modell egydimenziós jellegének korlátait mutatja, hogy a lakossági és civil részvétel formái nem feltétlenül a tipológia ugyanazon fokának jellegzetességeit mutatják (informált, de nem feltétlenül meghallgatott lakosság, tiltakozó vagy épp konzultációba bevont lokálpatrióta szervezetek, professzionális, akár partnerségi viszonyban is megjelenő nagyobb civil szervezet stb.). Arnstein kategóriái tehát használhatók a szereplök közötti különféle kapcsolatok leírására, de nem egy egydimenziós skála fokozataiként, hanem inkább kapcsolattípusokként, amelyek a szereplők között a tervezés során felmerült kapcsolatok különféle fajtáit írják le.

A kapcsolatok e sokfélesége jól elhelyezhető a Maier által felvázolt sajátos térben (Maier 2001). A hatalmi centrumhoz viszonylag közeli csoporthoz, a tanácsadók és intézményesített ellenzők közé sorolhatóak azok a véleményezési eljárásba bevont helyi szervezetek, amelyekkel konszolidált módon alakul az önkormányzat viszonya (pl. lokálpatrióta csoportok), egyes esetekben idetartoznak nagyobb, professzionális civil szervezetek, például a Levegő Munkacsoport is (amikor a formális véleményezési eljárásban megjelenik, illetve alternatív javaslattevőként lép fel). A konfliktushelyzetekben megjelenő lakosok, lakossági csoportok és egyéb szervezetek a hatalmi központtól messzebb, a küzdő ellenzők, tiltakozók közé sorolhatók. Az informált, nem feltétlenül meghallgatott csoportba tartoznak egyes lakossági fórumokon felbukkanó lakossági tiltakozók. A legtöbb részt vevő civil szervezet esetében megjelenik az a legitimációs igény, amely elfogadott, intézményesített tiltakozóvá tenné őket, sö́t nagyobb civil szervezetek esetében akár a partnerség (alternatív tervkoncepciók kidolgozása) felé is történik elmozdulás (tehát Maier modellje dinamikájában is értelmezhető a vizsgált helyzetre), utóbbi esetben ez sokszor a szervezet által megállapított stratégia része.

Ami a többi felvetett elméleti szempont közül a reprezentativitás kérdését illeti, a tervezési folyamatokban megjelenő lakossági csoportok a bevonás legelterjedtebb formáinak sajátosságai következtében számszerúen a lakosság kis arányát képviselik, továbbá nagy valószínủséggel nem reprezentálják az érintetteket. A lakossági fórumokon való részvétel alacsony szintje, illetve a megkérdezettek véleménye is arra utal, hogy több „szürö” is van, melyek alakítják a résztvevők körét: azok jelennek meg a lakossági fórumokon, akiknek tudomására jutott, nagyfokú érintettséget és/vagy érdeklődést mutatnak, közülük is elsősorban azok, akik ellenzik az adott 
Csanádi Gábor - Csizmady Adrienne - Köszeghy Lea : Nyilvánosság és részvétel a településtervezési folyamatban. - Tér és Társadalom 24. évf. 2010/1. 15-36. p.

TÉT XXIV. évf. 2010 - 1

Nyilvánosság és részvétel a ...

25

tervjavaslatot. Ez önmagában arra utal, hogy nem reprezentatív a megjelentek köre. A lakossági és egyéb civil szervezetek tagsága is nagyrészt értelmiségiekből áll, tehát a társadalom egyéb csoportjai közvetlenül kevéssé képviseltetik magukat, a professzionális civil szervezetek pedig sokszor nem is közvetlenül bizonyos lakossági vagy egyéb csoportok, hanem ügyek képviseletében (pl. élhető környezet megteremtése) lépnek fel. Összességében elmondható, hogy a részvételre irányuló törekvések csaknem kizárólag azokat érik el, akik ezért aktívan tesznek, esetleg tettek a múltban (pl. civil szervezet alakításával). „.. [a] már alkalmazott participációs mechanizmusok a lakosságnak és a vállalkozóknak csak azon csoportjait képesek elérni, amelyek magukat lobbiként definiálták, megnevezték" (KrémerVárnai 1996, 91). Az egy-egy konkrét területen kifejeződő, a területhez kötődő érdekek alapján felmerülö ellenvéleményben, konfliktusban az érdekeket képviselö lakossági csoportok vagy egyéb szervezetek feltehetôen az ott élők szélesebb körét képvíselik a gyakorlatban, de arra vonatkozóan, hogy ténylegesen mekkora ez az arány, reprezentatív lakossági véleménykutatás nélkül nem adható becslés.

A hazai településtervezés gyakorlatának elemzése kapcsán számos, elméleti megfontolások szempontjából is releváns kérdés lenne még kiemelhetö; e helyütt még egy kérdéssel foglalkozunk: mi a vizsgált tervezési folyamatok logikája? A törvény részletes, feszes ütemezésủ eljárásrendet állapít meg, a lakosságnak, a civil szervezeteknek ehhez a logikához kell alkalmazkodniuk. A szakirodalomban több helyen is felvetödó tétel, hogy a lakossági részvétel kétségkívuil idöigényes folyamat (pl. Lukovich 1997), amit a hazai tervezési rendszer nehezen tud kezelni. Emellett a vizsgált esetek tanúsága szerint a tervkidolgozás során az tud figyelembevételre nagyobb esélyú véleményt megfogalmazni, aki beszéli a tervezés szaknyelvét, vagyis valamilyen szinten szakértóként lép fel. Ez az egyik oka a nagyobb civil szervezetek professzionalizálódásának is: lényegében alkalmazkodnak a tervezés logikájához (ami számos esetben a szervezet tudatos stratégiája). A folyamatok e jellege azonban egyúttal azt is jelenti, hogy azok a lakosok, lakossági tiltakozások nyomán létrejövő lakossági szervezetek, amelyek ezzel a tudással nem rendelkeznek, nem képesek érdemben részt venni a tervezésben. Emiatt is fordul elö sokszor, hogy nagyobb, professzionális civil szervezetek segítségét kérik (amelyek aztán számos esetben „áthangszerelik” a tiltakozás tematikáját is, az általuk képviselt általános ügyeknek megfelelően). A rendszer említett jellegzetességei egyébként felértékelik az építész-várostervezők és a foópítészek szerepét is, akik birtokában vannak a tervezés bürokratikus és szakmai tudásának. A bürokratikus és szakmai orientációra utal az is, hogy - legalábbis a vizsgált esetekben - ritkán jelenik meg valamely más bevonási technika (ilyen volt egy-egy esetben az elözetes kérdöíves felmérés, a teruiletre kivitt lakossági fórum), inkább a törvény által elöírt formákat alkalmazzák. A tervezési folyamat sajátossága egyúttal arra is utal, hogy a hazai tervezési gyakorlatban hangsúlyosabb a cél-, mint a folyamatorientáció szerepe ${ }^{6}$. 
Csanádi Gábor - Csizmady Adrienne - Kőszeghy Lea : Nyilvánosság és részvétel a településtervezési folyamatban. - Tér és Társadalom 24. évf. 2010/1. 15-36. p.

26 Csanádi G.-Csizmady A.-Köszeghy L. TÉT XXIV. évf. 2010

\section{Lakossági és egyéb érdekek a tervkészítés folyamatában- egy survey tanulságai}

A participációt most a tervkészítési folyamat részeként fogjuk elemezni, és körbejárjuk azokat az aktorokat és a tervezők róluk kialakult képét, akikkel a tervkészítés során kapcsolatba kerülnek. Az elemzés fővárosi és Pest megyei településtervezőkkel, fóépítészekkel 2008-ban készített survey eredményein alapul.

\section{Kulcsszereplök}

A tervezési folyamat három kulcsszereplöjének az önkormányzatokat, a befektetőket és a lakosságot tekintettük. Arra voltunk kíváncsiak, hogy a gyakorló tervezők szerint a jelenlegi (2008-as) helyzetben kinek van nagyobb befolyása a tervezési munkára. A válaszadóknak a befolyás mértéke szerint 10 pontot kellett elosztaniuk a három csoport között (2. táblázat). Az átlagos vélemény szerint az önkormányzat és a befektetöi csoport hasonlóan nagy befolyású (az átlagpontszám 4 és 4,3 volt), míg a lakosság sokkal kevésbé (1,7 pont). A megkérdezett tervezők ugyanakkor azt tartanák optimális helyzetnek, ha ezek az arányok lényeges eltérést mutatnának: az önkormányzat befolyása kicsit magasabb $(4,2)$, viszont a vállalkozóké jelentősen kisebb (2,7), a helyi lakosságé pedig majdnem kétszer akkora volna, mint a most tapasztalható $(3,1)$.

\section{TÁBLÁZAT}

Az önkormányzati, befektetói és lakossági csoportok tervkészítésre gyakorolt befolyásának jelenlegi és optimális mértéke, 2008 (átlagérték a tízpontos skálán) (Level of the Present and Optimal Influence of the Stakeholders in Planning, 2008)

\begin{tabular}{clcc}
\hline \multicolumn{1}{c}{ Idōtáv } & $\begin{array}{c}\text { Csoport } \\
(\mathrm{N}=255)\end{array}$ & Átlag & Szórás \\
\hline \multirow{3}{*}{ Jelenlegi befolyás } & Önkormányzat & 4,0 & 1,3 \\
& Befektetők & 4,3 & 1,3 \\
& Helyi lakosság & 1,7 & 0,7 \\
\hline \multirow{3}{*}{ Optimális befolyás } & Önkormányzat & 4,2 & 1,2 \\
& Befektetők & 2,7 & 0,9 \\
& Helyi lakosság & 3,1 & 1,2 \\
\hline
\end{tabular}

Forrás: Survey (2008).

Az adatokból az is sejthetö, hogy a tervezők között nagy súlya van annak a véleménynek is, amely a lakosság beleszólását nem látja indokoltnak:

„Igény a befektetőnél keletkezik, Önkormányzat ellavíroz ennek megfelelően. Lakosságnak nem kell 1-nél több befolyást adni, hiszen nem ért hozzá. Szakmai alapon az önkormányzat jobban átlátja, neki feladata eldönteni." 
Csanádi Gábor - Csizmady Adrienne - Köszeghy Lea : Nyilvánosság és részvétel a településtervezési folyamatban. - Tér és Társadalom 24. évf. 2010/1. 15-36. p.

A participációval szembeni ellenérvek egyikét talán a fenti idézet foglalja össze a legjobban. A másik nem is annyira ellenérv, mint egy rendszer funkcionális müködésébe vetett hit - mely a tervezỏ szempontjából nézve nagyon is leegyszerüsítené a helyzetet: „Ha feltételezzük, hogy az önkormányzat a lakosságot képviseli, akkor jól van a jelenlegi helyzet”, sőt többen látják úgy, hogy ,az optimális az lenne, ha nem tehetö különbség a helyi önkormányzat és a lakosság között."

A tervezők különböző csoportjai számára érthető módon nem is annyira az érintett lakosság és az önkormányzat közötti viszony a leginkább lényeges kihívás, hanem a vállalkozók térnyerése kapesán felmerülö kérdések. Sokszor ambivalensek, hiszen éppen a tókeerős vállalkozóknak köszönhetik a munkájuk iránti kereslet döntő részét, ugyanakkor az adott döntési mechanizmusokban kiszolgáltatottságuk növekedését is tapasztalják.

A helyzettel való elégedetlenség nemcsak a várostervezők esetében derült ki, hanem az önkormányzati tisztviselökkel folytatott interjúk is erről tanúskodnak. A beruházók (különösen a külföldiek) erős hatalma mögött az önkormányzatok tơkeszegénysége áll. A lakóparkok terjedése például jól mutatta, hogy különösen az ezredforduló környékén a beruházói igényeket, kéréseket nagyrészt teljesítették, hiszen a kerületi/települési vezetők úgy látták, hogy minden lehetőséget meg kell ragadniuk ahhoz, hogy a kerület/település fejlődni tudjon.

„Önkormányzat ki van szolgáltatva a befektetőnek, ha nem jönnek, az a település meghalt. Tervezôt is neki kell rendezni, és még fizetni is önkormányzatnak utat, közmủveket, mert kevés a pénze. Lakosság ritka hogy véleményt alkot. Csak tájékoztatni kell! 30 napra kifüggeszteni. [Ez] törvényi elöírás, nem lehet kihagyni." (önkormányzati hivatalnok)

Így aztán a rendezési tervek módosításakor a tervezők az elmúlt években számos alkalommal olyan alkukba is belementek, amelyekről esetleg azt (is) gondolták, hogy hosszú távon visszaütnek az önkormányzatokra (pl. a beruházás nyomán bủvölö lakosságszámhoz kapcsolódó pluszszolgáltatások miatt - közlekedési infrastruktúra fejlesztése, növekvő létszám az egészségügyi, oktatási ellátórendszerben -, és amelyek finanszírozására nem volt elég kerete az önkormányzatnak). A problémán az utóbbi években - amikor az esetek egy részében kevésbé látják egyenlőtlennek az esélyeket arra, hogy követelményeket támasszanak a beruházókkal szemben - úgy próbálnak úrrá lenni, hogy a kapcsolódó fejlesztések minél nagyobb részét a beruházóra próbálják áthárítani. A (potenciális) befektetők ezt természetesen méltánytalannak tartják, és a tervező szakemberekkel együtt úgy ítélik meg, hogy a „,szakmaiság" helyett az alkuk alapja a sima erőfölény érvényesítése - rosszabb esetben a nyîlt vagy burkolt korrupció.

A befektetői befolyás tehát nagy, és a tervezési folyamatban részt vevő tervezö aki ugyan formálisan az önkormányzattól kapja a megbízást - rendszerint mégis túlzottnak érzi a vállalkozói befolyást: „Ha odamegy a befektető, és akar valamit, akkor az van" - fogalmaznak. Ráadásul, mivel a tervváltoztatás költségét a beruházóval fizetteti meg az önkormányzat, a befektető sokkal inkább érezheti úgy, hogy a pénzéért meghatározhatja, milyen tervekhez-döntésekhez kíván hozzájutni. 
Csanádi Gábor - Csizmady Adrienne - Köszeghy Lea : Nyilvánosság és részvétel a

településtervezési folyamatban. - Tér és Társadalom 24. évf. 2010/1. 15-36. p.

28 Csanádi G.-Csizmady A.-Köszeghy L.

TÉT XXIV. évf. 2010

Ebben a helyzetben a tervezö is kiszolgáltatottnak érzi magát, hiszen nem képes saját értékrendszerének érvényesítésére, vagy akár a lakossági igények mélyebb artikulálásának elősegítésére.

„A befektetők diktálnak, mindent meg kell csinálni nekik. A szakmailag rosszat is megcsinálja az önkormányzat, mert ök (a befektetők) azt találják ki." Némely tervezö az utóbbi évek gyakorlata alapján egyenesen olyan szélsőséges helyzetet lát maga körül, mely szerint „az önkormányzat és a befektető nem elkülöníthetők”, sőt „a befektető mindig eléri a célját, a hatóságok ellenében is"7 .

Ebben a helyzetben tehát igen nehéz egy tervezőnek, amikor saját szerepét kell definiálnia. A tervezök közel kétötöde (38,9\%) mégis úgy érzi, hogy szükség van a helyiek környezeti érdekeinek képviseletére a politikusokkal szemben, és elenyészö azok aránya (3,9\%), akik a tervező feladatát kizárólag abban látják, hogy a helyi önkormányzat igényeinek megfelelö terveket készítsenek. A tervezők több mint fele (58\%) azonban úgy gondolja, hogy a tervező feladata az, hogy az önkormányzattal együttmüködve, az igényeket figyelembe véve végezze a munkáját.

\section{Participáció}

A tervezési munkálatokba a törvényi elöírásoknak - és formálisan a nyugati gyakorlatnak - megfelelően több esetben valamilyen módon, bizonyos mélységig megpróbálják bevonni azokat a szereplőket, akik érintettek lesznek az átalakulásokban. Bár több olyan vélemény is van, mely szerint

„(...) nincs értelme a részletes igényfelmérésnek (sem). Ha mindenkit megkérdeznének, akkor nem lehet annyi igényt figyelembe venni és számon kérik, hogy az övé miért nem valósult meg, nem lehet minden kérést figyelembe venni!" ${ }^{8}$

Ebben a helyzetben akár pozitív fejleménynek is tarthatjuk, hogy a tervezök 42,7\%-a számolt be arról, hogy a tervezési munkálatok elökészítéséhez közvélemény-kutatást végeztek. (Természetesen azt nem tudjuk, hogy a véleményfelmérés milyen mélységủ volt és mekkora mintán zajlott, mindenesetre az tény, hogy igény volt a lakosság helyzetének és véleményének ily módon való megismerésére.) Ráadásul az elvégzett kutatások az esetek nagy részében $(78,2 \%)$ segítséget is nyújtottak - bár volt néhány eset, amikor inkább nehézséget okozott a sokféle vélemény megismerése, különösen azoké, amelyek esetleg ellentétesek voltak a városvezetés változtatási szándékaival.

A lakossági fórum az egyeztetési folyamatnak még mindig a legnehezebb és legproblematikusabb része; szükségességének, hasznosságának megítélése megosztja a tervezőket: 90,4\%-uk válaszolta azt, hogy tervezési munkái során tartanak ilyen jellegü egyeztetéseket, ám csak kicsivel több mint felük vélte úgy, hogy a fórum segített, és egyötödük szerint inkább nehezítette a tervezés folyamatát (és szinte ugyanekkora volt azok aránya, akik szerint semmilyen hatása sem volt).

A tervezök 45,6\%-a úgy érzi, hogy a civil, lakossági részvétel fontos akadálya a szaktudás hiánya. Sokan ellenzik is, mivel értelmetlennek tartják, hogy a szakmai 
Csanádi Gábor - Csizmady Adrienne - Kőszeghy Lea : Nyilvánosság és részvétel a településtervezési folyamatban. - Tér és Társadalom 24. évf. 2010/1. 15-36. p.

kérdésekben nem járatos embereket is bevonjanak: „A lakossági fórum egy áldemokratikus baromság, eljátsszák, hogy mindenki elmondja a véleményét szakmai szempontból értékelhetetlen." Esetleg haszontalannak tartják, hiszen a tervezök elég gyakran találkoznak azzal, hogy a „lakossági fórumnak nem volt hatása - elöre lehetett tudni, hogy mi lesz".

A tervezök szerint a lakossági fórum túlságosan függ a politikusoktól, illetve a politikai helyzettől. Ennek jó példája egy olyan vidéki város, ahol mostanában egy tisztán városfejlesztési problémával foglalkozó lakossági fórum más okokból feszült politikai helyzetben valósult meg. Ez olyan szokatlan és bizonytalan körülményeket teremtett a várostervezők számára, hogy még a lakossági fórumok gyakorlatán is változtatniuk kellett - „,nehogy belekössenek valamibe”. Egy lakossági fórum korábban általában úgy zajlott, hogy a tervek ismertetése után egy-két kérdésre még lehetôséget adtak, de egy óra alatt befejezték az egész rendezvényt, hiszen a lakosság egy-egy ilyen fórum során úgyis mindenröl beszél, ami csak eszébe jut, mindegy, hogy a témához tartozik-e, vagy sem. Ebben a helyzetben azonban kénytelenek voltak az öszszes lakossági hozzászólást meghallgatni, ami időben jelentősen kitolta a rendezvényt.

Összességében talán azt mondhatnánk, hogy egy lakossági fórum sikere függ a politikai közegtől, attól, hogy mennyire akarják megtudni a véleményeket és attól, hogy milyen érdeklödésre tart számot a kérdés, mennyire ütköznek az érdekek az adott területtel kapcsolatban: „A lakossági fórumok akkor kerülnek magasabb szintre, ha konfliktus van." Gyakori vélekedésnek tünik, hogy a jelenlegi tervezési folyamatba nem fér bele, hogy a tervezó hosszas, több alkalmas egyeztetéseket folytasson a civilekkel és a lakossággal. A tervezók több mint egyötöde úgy vélekedik, hogy a tẹlepuilésfejlesztés irányainak a meghatározása során nem neki kellene a lakossági vélemények feltárásával foglalkoznia. Ez a tervezői munka professzionalizálódásának folyamatába illik bele, a világmegváltó tervező helyett a professzionális - „mondják, meg mit akarnak és én megcsinálom” - típus irányába kacsingat a szakma egy része: „Neki müködnie kell, nem véleményt feltárni. Tervező végrehajtja. A politika dolga az, hogy tisztában legyen az igényekkel." A tervező leginkább hivatalnok szeretne lenni, akinek ugyan nyilvánvaló, hogy a tulajdonképpeni megrendelő a lakosság, de ezt ebben a pozícióban távol lehet tartani, és az ,aki fizet, az a megrendelő" szemléletet lehet továbbra is erősíteni: „Ezért vannak a szakbizottságok. Az önkormányzat feladata, az önkormányzat áll a lakosság és a tervezö között."

A tervezők nagy része $(77,7 \%)$ ugyanakkor a településfejlesztés irányainak a meghatározása során saját feladatának is érzi a lakossági egyeztetéseket. A helyi politikusoknak, a helyi szakapparátusnak, az erre specializálódott szakértőknek és a civil szervezeteknek nagyobb, viszont a gazdasági szereplőknek kisebb szerepet szán ebben a feladatban (3. táblázat). 
Csanádi Gábor - Csizmady Adrienne - Köszeghy Lea : Nyilvánosság és részvétel a

településtervezési folyamatban. - Tér és Társadalom 24. évf. 2010/1. 15-36. p.

\section{TÁBLÁZAT}

„Ön szerint a településfejlesztés irányainak a meghatározása során kinek vagy kiknek szükséges a lakossági vélemények feltárásával foglalkoznia?" - a tervezók válaszai ${ }^{*}, 2008(\%)$

(Who Should Consider the Opinion of Inhabitants?)

\begin{tabular}{lcc}
\hline $\begin{array}{l}\text { Ki foglalkozzon a lakossági vélemé- } \\
\text { nyekkel? }\end{array}$ & Szükséges & $(N=)$ \\
\hline Helyi politikusok & 85,8 & $(260)$ \\
Helyi szakapparátus & 74,5 & $(259)$ \\
Tervező & 77,7 & $(260)$ \\
Erre specializálódott szakértők & 87,0 & $(253)$ \\
Civil szervezetek & 78,9 & $(256)$ \\
Gazdasági szereplök & 42,2 & $(254)$ \\
\hline
\end{tabular}

* Több válasz volt lehetséges.

Forrás: Survey (2008).

Mindenesetre leginkább a közös, több oldalról való véleményfeltárást tartanák jónak, „mindenkinek kellene, de nincs erre idő és pénz”. De - a pénzen kívül többek között a szakértelem és az apparátus is hiányzik:

„(..) a civilek ütődöttek, kellene foglalkozniuk ezzel, de nem tudják", ,a szakapparátusnak [pedig] fel kellene nönie, ha másmilyen lenne a politika." Ráadásul többen vélik úgy, hogy markánsabb határokat kellene húzni, és föleg betartani az egyes csoportok kompetenciáját figyelembe véve: ,a politikusok politizáljanak, és ne üssék bele az orrukat müszaki dolgokba. Szakértỏ kellene, de nincs pénz rá. Gazdasági szereplők viszont ne tegyék, mert nem értenek hozzá. Önkormányzatoknak kellene, csak sokkal hatékonyabban."

Ebben a csoportban is találunk azonban olyan tervezöt, aki a szakfeladaton felül lényegesen nagyobb szerepet akar magára vállalni, és azt gondolja, hogy a „tervezőnek kell generalistának lennie, neki kell feltárni, nem a szociológusnak például." Ez az álláspont viszont a professzionalitás hiányán túl - hiszen a tervező ritkán szociológus vagy közgazdász is egyben - ismét felveti a tervezö mint a társadalmi problémák világmegváltó kezelỏje álláspont ismeretes dilemmáit.

A tervezők közül egyre többen $(74,2 \%)$ számolnak be arról, hogy a kötelező egyeztetéseken kívül vannak külön megbeszélések helyi érdekcsoportokkal, hiszen „fontos, hogy megismerjék a terveket, észrevételek beépíthetők legyenek”, és a megbeszélések általában pozitív viszonyban vannak a tervezési folyamattal. Mégis vannak olyan tervezők $(9,7 \%)$, akik nem állnak lelkesen az ilyen egyeztetések mellé. Van, aki úgy érzi, hogy „nem ők [akikkel egyeztettek] voltak hatással a tervezésre, hanem mi voltunk hatással a csoportra". Van, akit nem a folyamat, hanem a helyi adaptáció, a helyi viszonyrendszer átláthatatlansága is zavar:

„még nem alakult ki a kultúrája, ez ritkán jó. Például a ... esetében az érdekcsoportok[kal] - a: gengszterek, b: őslakosok, c: új betelepülök - csak akkor lehet tárgyalni, ha jól körülhatárolt érdekcsoportok vannak. Itt nem is lehet tisztán látni, ki kit képvisel." 
Csanádi Gábor - Csizmady Adrienne - Köszeghy Lea : Nyilvánosság és részvétel a településtervezési folyamatban. - Tér és Társadalom 24. évf. 2010/1. 15-36. p.

Már sokkal ritkábban kerül sor arra, hogy a szakági tervezőkön kívül más szakmák képviselöit (pl. közgazdászok, szociológusok) is bevonják a tervezési folyamatba, a tervezök 61,3\%-a számolt be ilyenről. Ők viszont szinte kivétel nélkül úgy vélekedtek, hogy az együttmüködés sikeres volt, és segített nekik a megfelelöen jó terv elkészítéséhez. Ahol ez még nem gyakorlat, ott is lenne igény rá, a tervezők hiányolják is; van, akik nem közvetlenül, hanem közvetve ismerkednek más szakmák szempontjaival, például a városszociológiai irodalmon keresztül.

\section{Konfliktusok a tervelfogadás során}

A tervezési munkákban több szereplővel kell együttmüködnie a településtervezőnek, az együttmúködés foka és minősége is különbözö lehet az egyes szereplök esetében. A főépítészek és tervezők, a szakági tervezők, a polgármester és a szakértők képviselöi között az esetek nagy részében megteremtödik az összhang. Sokkal konfliktusosabb viszonyról számoltak be viszont a gazdasági szereplők, a képviselötestületek, a szakhatóságok, a civil szervezetek és a lakosság esetében. Nézzük meg, milyenek ezek a konfliktusok (4. táblázat).

\section{TÁBLÁZAT}

Az együttmüködés jellemzöje a tervezési folyamat egyes szereplöivel, 2008 (\%) (Typology of the Cooperation in the Planning Process)

\begin{tabular}{|c|c|c|c|c|c|c|c|}
\hline Szereplö & $\begin{array}{l}\text { Konflik- } \\
\text { tusos }\end{array}$ & $\begin{array}{l}\text { Együtt- } \\
\text { müködö }\end{array}$ & $I s-i s$ & Semleges & $\begin{array}{c}\text { Nem volt } \\
\text { s kapcso- } \\
\text { lata }\end{array}$ & $\begin{array}{c}\text { Ösz- } \\
\text { szesen }\end{array}$ & $(N=)$ \\
\hline $\begin{array}{l}\text { Föépítész (a tervezök } \\
\text { esetében) }\end{array}$ & 4,5 & 62,3 & 23,1 & 1,5 & 8,5 & 100,0 & (199) \\
\hline $\begin{array}{l}\text { Tervezö (a fóépítészek } \\
\text { esetében) }\end{array}$ & 0,0 & 75,3 & 23,5 & 1,2 & 0,0 & 100,0 & (85) \\
\hline Helyi szakapparátus & 3,9 & 60,4 & 25,1 & 5,5 & 5,1 & 100,0 & $(255)$ \\
\hline Képviselö-testület & 9,7 & 25,6 & 38,8 & 11,2 & 14,7 & 100,0 & $(258)$ \\
\hline Szakhatóságok & 9,7 & 38,4 & 41,5 & 5,4 & 5,0 & 100,0 & $(258$ \\
\hline Civil szervezetek & 9,3 & 29,8 & 34,9 & 10,1 & 15,9 & 100,0 & $(258)$ \\
\hline Lakosság & 6,6 & 26,4 & 38,0 & 17,1 & 12,0 & 100,0 & $(258)$ \\
\hline Gazdasági szereplők & 11,7 & 30,5 & 39,5 & 7,4 & 10,9 & 100,0 & $(259)$ \\
\hline Polgármester & 4,2 & 58,7 & 21,2 & 5,0 & 10,8 & 100,0 & $(256)$ \\
\hline Szakági tervezök & 4,2 & 58,7 & 21,2 & 5,0 & 10,8 & 100,0 & (259) \\
\hline $\begin{array}{l}\text { Külsó szakértők } \\
\text { képviselői }\end{array}$ & 3,1 & 61,3 & 6,6 & 4,7 & 24,2 & 100,0 & (259) \\
\hline
\end{tabular}

Forrás: Survey (2008).

A korábbiakban többször felmerült, hogy bizonyos esetekben a participáció olyan konfliktusokat is okozhat, amelyek „,föleg egyéni érdek és közérdek összeütközéséből adódtak", és megnehezítik, vagy éppen lehetetlenné teszik a folyamatot.

A pozitív nézet szerint ,konfliktus mindig van, ki kell egyenlítődni, nem lehet válasz nélkül hagyni, ez egy egyeztetési folyamat értelme". Ennek ellenére gyakran 
Csanádi Gábor - Csizmady Adrienne - Kőszeghy Lea : Nyilvánosság és részvétel a

településtervezési folyamatban. - Tér és Társadalom 24. évf. 2010/1. 15-36. p.

32 Csanádi G.-Csizmady A.-Köszeghy L.

TÉT XXIV. évf. 2010

nehéz szót érteni a résztvevőkkel, „nemcsak a laikus politikusoknak, minden laikusnak nehéz megmagyarázni" mindazt, ami a tervezőnek magától értetődő.

Természetesen, amikor egy tervet nem a tervező elképzelésének megfelelően fogadnak el (52,2\% számolt be erről), a tervező nehezen tud optimistán tekinteni az egyeztetésekre. Ilyen esetekkel kapcsolatban két szcenárióról számoltak be: vagy csak a terv egyes részeit szavazták le, és ,,a terv bizonyos elemeiben rosszízủ kompromiszszumokra kényszerültünk az önkormányzat miatt", vagy az egészet elutasították: „„örtént ilyen, ráírtam a tervre, hogy tervezöi javaslat ellenére történt”. Akkor van talán nagyobb gond, ha nemcsak a helyi érdekek, hanem országosak is szerepet kapnak; ilyen esetekben a tervező helyzete nagyon negatívvá is válhat: „Nem csak helyi, országos döntéshozókkal is volt olyan, hogy leszavazták a tervezöi javaslatot. Volt olyan, hogy olyan lépett életbe, amivel nem értettem egyet, de akkor kirúgtak."

Nézzük meg részletesen is az egyes konfliktustípusokat (5. táblázat). Az, hogy a helyi döntéshozók politikai okokból leszavazták a tervezői javaslatot, a válaszolók 60,2\%-ának praxisában fordult elö. Az egyeztetéseket 78\% szerint nagyban megnehezíti, hogy ,a laikus politikusoknak nehéz volt egy-egy szakmai javaslat elmagyarázása”. A terveket gyakran „,politikai, illetve GAZDASÁGI okból szavazták le”. Vannak azonban olyan tervezök is, akik jónak tartják, ha a politikai erő időben vétót emel, hiszen „,nem a végén kell, hogy kiderüljön, hogy a politikusok nem támogatják”.

\section{TÁBLÁZAT}

„A tervezési munkálatokhoz kapcsolódóan elöfordult-e, hogy..."

- az igen válaszok aránya, 2008 (\%)

(Forms of Participation in the Planning Process)

\begin{tabular}{|c|c|c|}
\hline Elöfordult-e, hogy... & Igen & $(N=)$ \\
\hline $\begin{array}{l}\text {...Ön mint tervezö szakmailag nem értett egyet a tervvel, mégis } \\
\text { ez lépett érvénybe? }\end{array}$ & 52,5 & $(255)$ \\
\hline $\begin{array}{l}\text {...a helyi döntéshozók politikai okokból leszavazták a tervezői } \\
\text { javaslatot? }\end{array}$ & 60,2 & (256) \\
\hline $\begin{array}{l}\text {...a laikus politikusoknak nehéz volt egy-egy szakmai javaslat } \\
\text { elmagyarázása? }\end{array}$ & 78,0 & $(256)$ \\
\hline $\begin{array}{l}\text {.. a tervezést magánberuházó finanszírozta, és ezzel összefüggés- } \\
\text { ben befolyásolni kívánta a tervek tartalmát? }\end{array}$ & 78,0 & (256) \\
\hline ...a helyi lakosság (vagy ebböl alakult szervezet) tiltakozására? & 52,9 & $(261)$ \\
\hline ...civil szervezetek bevonására a véleményezési folyamatba? & 84,0 & $(257)$ \\
\hline $\begin{array}{l}\text {...konfliktusra civil szervezettel (pl. környezetvédök) a tervezés } \\
\text { kapcsán? }\end{array}$ & 47,5 & $(256)$ \\
\hline $\begin{array}{l}\text {...a lakossági, civil fellépés szükebb érdekek érvényesüléséhez } \\
\text { vezetett, a közérdek sérelmére? }\end{array}$ & 42,1 & (259) \\
\hline $\begin{array}{l}\text {...a civil, illetve lakossági részvétel új, használható ötleteket ho- } \\
\text { zott a tervezésbe? }\end{array}$ & 63,7 & (256) \\
\hline
\end{tabular}

Forrás: Survey (2008).

Gyakran (78\%) okoz konfliktust az a már említett gyakorlat, hogy a tervezést a magánberuházó finanszírozza, és ezért az esetek jelentös részében befolyásolni is 
Csanádi Gábor - Csizmady Adrienne - Köszeghy Lea : Nyilvánosság és részvétel a településtervezési folyamatban. - Tér és Társadalom 24. évf. 2010/1. 15-36. p.

kívánja a tervek tartalmát. Ezt a törekvést több tervezỏ normálisnak tartja, sőt úgy érzi, hogy gyakran pozitív irányba mozdította elő a tervezést a beruházó ötlete, célja. Az esetek egy részében a beruházó „nyertesként” keriul ki a folyamatból, más részében viszont „elöfordul, hogy próbál befolyásolni, de nem biztos, hogy jóváhagyják, amit szeretne".

A tervezők több mint a fele keveredett konfliktusba a lakossággal, és sokan érzik úgy, hogy a konfliktusok nem visznek elöre: „itt sem érdemi dolgok szoktak lenni”. Sỏt „nem logikus a tiltakozás a lakosságnál, attól függ hogy van-e helyi hangadó”, ám a kialakult konfliktus ,egyeztetésekkel eddig mindig rendezésre került”.

Sokkal konfliktusosabbnak érzik a helyzetet a hazai civil szervezetekkel, bár csak a tervezők majdnem fele keveredett már komolyabb konfliktusba velük. Mivel az Étv. szerint a véleményezési folyamatba kötelezỏ bevonni öket, a bevonás a válaszolók 84\%-ának praxisában meg is történt, ám a hasznosságról megoszlanak a vélemények. Többen vélik úgy, hogy az egyeztetésnek nem volt haszna, és a civilek képzetlenek a területet illetően, „későn jut el hozzájuk az információ, vagy képtelen-lehetetlen dolgokat képviselnek”, sôt gyakran ellenségesek és kevésbé együttmüködők: „Olyan mértékben buták hogy nem értik-nem indokolják meg a véleményüket." Más vélemények szerint nincs igazán haszna a civilek bevonásának, „a civil szervezetek lényege, hogy a lakossággal foglalkozzanak", az ő szélesen vett érdekeiket képviseljék. Ez azonban ma még gyakran nem így sikerül, ezért több tervező gondolja úgy, hogy „civil szervezet fogalmát, játékszabályait pontosítani kellene”.

A tervezők $42,1 \%$-a gondolja úgy, hogy a lakossági és/vagy civil fellépés szükebb érdekek érvényesüléséhez vezetett, a közérdek sérelmére. Ugyanakkor $63,7 \%$ érezte úgy, hogy a civil, illetve lakossági részvétel új, használható ötleteket (is) hozott a tervezésbe. A helyzet tehát igen bonyolult, konfliktusokkal teli többdimenziós térben értelmezendő. Sokan érzik úgy, hogy az egyeztetés semmi pluszt nem ad a tervezéshez, hiszen a laikusok nincsenek abban a helyzetben, hogy érdemben hozzá tudnának szólni a „,dolgokhoz”.

Van, amikor ezek az érdekek, ötletek nem is a civilektöl vagy a lakosságtól erednek, hanem láthatatlanul bár, de a politika áll mögötte: „politikus által felkeltett módon, nem önállóan történt. Új használható ötletekre lenne szükség, de Magyarországon ilyen nem létezik."

És van olyan is, amikor valamelyik civil szervezet ebböl a pozícióból akar belépni a politikai erőtérbe, bizonyos értelemben hatalmat kíván magának szerezni:

$$
\begin{aligned}
& \text { „A ... kerületben szükebb civil érdekcsoport befolyásolta a terveket. Nagyon kevés } \\
& \text { valódi érdeket képviselnek. Kvázi civilként akarnak bemenni a hatalomba. Az a baj a } \\
& \text { városfejlesztési folyamattal, hogy úgy tesznek, mintha tudnák, mit játszanak. És talán } \\
& \text { ez utóbbi a legveszélyesebb, ha meggondoljuk, hogy a döntéseknek idöben milyen } \\
& \text { messzire nyúló hatásai vannak." }
\end{aligned}
$$

Van, hogy a tervezők értetlenül állnak a lakosság viselkedése elött, mely szerintük nem magyarázható meg a racionális keretek felhasználásával: „belvárosi slumos tömbben az önkormányzat rendet akar vágni. A tömb lakói gazdaságilag is jobban járnának, és mégis megakadályozzák a rekonstrukciót." 
Csanádi Gábor - Csizmady Adrienne - Köszeghy Lea : Nyilvánosság és részvétel a településtervezési folyamatban. - Tér és Társadalom 24. évf. 2010/1. 15-36. p.

Az egész folyamatot gyakran inkább már csak időpocsékolásként élik meg maguk a tervezők is, és sok esetben tapasztaltuk, hogy már nem is igazán kíváncsiak a véleményekre, csak ,lezavarják" az egyeztetést.

Több esetben viszont kiderült, hogy mégis van értelme megismerni a véleményeket, hol önvédelemből (a terv és a tervező pozíciójának védelme miatt), hol pedig azért, mert néhány momentumban megfontolandó, esetleg jónak tartott ötletmorzsák kerülnek elö, melyek aztán kidolgozásra, beépítésre érdemesnek találtatnak.

\section{Konklúzió}

A rendszerváltás után az építész-várostervezők újfajta erőviszonyok közé kerültek a várostervezési folyamatban. Újfajta kötöttségként jelentkezik a piaci befektetőktől való erős függőség, az, hogy az önkormányzatok (eltérően a rendszerváltás előtti helyzettől, amikor az állami fejlesztési forrásokért folyt a verseny) most a piaci (és EU-s) fejlesztési forrásokért versengenek, ami újfajta dilemmákat vet fel a tervezők számárára (hogyan definiálják a szerepüket a befektetőkhöz képest)? Egyértelmüvé vált az is, hogy a tervezők a korábbiaknál erősebben függnek a helyi politikától, a tervezési folyamat sikeressége érdekében el kell hogy helyezzék magukat az adott önkormányzat erőviszonyai között. Összességében - figyelembe véve a lakosság, civil szervezetek növekvő aktivitását is - megnövekedett a laikus vélemények szerepe a tervezési folyamatban. Mindez a korábbi tervezői szerep elbizonytalanodásával, újradefiniálásának szükségességével jár, ami viszont az építész-várostervező szakma és a kapcsolódó szakmák intenzív párbeszéde, vitái, együttgondolkodása révén formálódhat ki.

\section{Jegyzetek}

${ }^{1}$ A tanulmány a település- és várostervezési folyamatnak azt az oldalát igyekszik elméletileg és empirikus anyag mentén is bemutatni, melyben a lakossági vélemények artikulálódnak, elsősorban a várostervezés néhány elméleti megfontolása és ene vonatkozó empirikus vizsgálatok alapján. A kutatómunka a következö kutatások keretében folyt: Studio Metropolitana Kht.-ELTE TÁTK „A településtervezés tényleges gyakorlata az önkormányzatoknál (2002)" esettanulmányok az FVM Terület- és Településrendezési Föosztálya számára (2009). Bolyai János Kutatási Ösztöndíj. Az OTKA 47142. számú „Várostervezés és a térbeni-társadalmi szerkezet változásai Budapesten", és a 68509. számú "A városrehabilitáció társadalmi hatásai" kutatásai, valamint a Norvég Alap által támogatott „Fenntartható termelés, fogyasztás és kommunikáció” kutatás „Városrehabilitáció törtténelmi környezetben” címủ alprojektje.

2 A participáció kifejezés alatt - bár önmagában mindössze részvételt jelent - sokszor automatikusan a lakossági részvételt és/vagy a civil szervezetek részvételét (amelyek valójában igen sokfélék lehetnek, a lakossági civil szervezetektől a professzionális, ügyképviseleti szervezetekig) szokás érteni. Mint később látni fogjuk, a két említett szereplő (szereplöcsoport) részvétele igen eltérỏ jellegú lehet.

${ }^{3}$ Lukovich Tamás értelmezésével szemben (Lukovich 1997) Arnstein ezt nem mindkét, a részvétel hiányával jellemezhetö fokozattal, csak a terápia fokozatával kapesolatban álítja.

4 Az aarhusi egyezményt az EU és a csatlakozásra váró országok - közöttük Magyarország - miniszterei írták alá 1998-ban Dániában. 
Csanádi Gábor - Csizmady Adrienne - Kőszeghy Lea : Nyilvánosság és részvétel a településtervezési folyamatban. - Tér és Társadalom 24. évf. 2010/1. 15-36. p.

${ }^{5}$ A törvényt a 2008. évi XLIX. törvény több helyen módosította, ez azonban nem érinti az itt tárgyalt szempontból lényeges részeket.

${ }^{6}$ A cél- vagy folyamatorientáció kérdése a tervezéselmélet egyik alapvető témája az utóbbi évtizedekben (lásd pl. Taylor 1999).

${ }^{7}$ Eltekintünk az igen gyakran emlegetett, többé-kevésbé nyîlt korrupció problémáitól. Nem azért, mintha ezt az aspektust lényegtelennek tartanánk, hanem azért, mert szociológiailag az a lényeges, hogy milyen feltételek teszik lehetővé a müködését. Itt ennek elemzésére nincs elég helyünk.

${ }^{8}$ Nem részletezzük, de jól elgondolható, hogy az ezt az álláspontot képviselök hogyan vélekednek arról, ha az érintetteknek nem csupán az igényeit próbálják felmérni, hanem a döntésbe való aktívabb beleszólás mechanizmusainak kialakítása is felmerül.

\section{Irodalom}

Arnstein, S. (2000) A ladder of citizen participation. - LeGates, R.T.-Stout, F. (eds.) The City Reader. Routledge, New York. 240-252. o.

Athéni Charta (1979) Az Athéni Charta. - Vidor F. (szerk.) Urbanisztika. Gondolat, Budapest. 150-161. o.

Atkinson, R. (2001) The emerging 'Urban Agenda' and the European Spatial Development Perspective:

Towards an EU Urban Policy? - European Planning Studies. 3. 385-406. o.

Davidoff, P. (2000) Advocacy and pluralism in planning. - LeGates, R.T.-Stout, F. (eds.) The City Reader. Routledge, New York. 423-433. o.

Fogarasi Gy. (1995) Területfejlesztés és participáció, - Társadalomkutatás. 1-4. 24-34. o.

Geddes, P. (1915 [2000]) City Survey for Town Planning Purposes, of Municipalities and Government. LeGates, R.T.-Stout, F. (eds.) The City Reader. Routledge, New York. 330-333. o.

Hall, P. (1996) The City of Theory. - LeGates, R.T.-Stout, F. (eds.) The City Reader. Routledge, New York-London. 383-396. o.

Hall, P. (2000) Cities of tomorrow. Blackwell, Oxford.

Jacobs, A.-Appleyard, D. (2000) Towards an Urban Design Manifesto. - LeGates, R.T.-Stout, F. (eds.) The City Reader. Routledge, New York-London. 492-502. o.

Krémer A.-Várnai G. (1996) Terülletpolitika és kommunikáció. - Comitatus. 7-8. 90-92. o.

Lukovich T. (1992) A közösségi részvételröl. - Valóság. 11. 19-29. o.

Lukovics T. (1997) A posztmodern kor városépítészetének kihivásai. Szószabó Stúdió, Budapest.

Maier, K. (2001) Citizen Participatin in Planning: Climbing a Ladder? - European Planning Studies. 6. 707-719. o.

Mayer, M. (2000) Post-fordist city politics. - LeGates, R.T.-Stout, F. (eds.) The City Reader. Routledge, New York. 230-239. o.

Meggyesi, T. (1985) A városépités útjai és tévútjai. Műszaki Kiadó, Budapest.

Ongjert R. (1999) A párbeszédben álló város. Gyakorlati útmutató a társadalmi részvétellel történő településtervezéshez. Studio Metropolitana Urbanisztikai Kutató Központ Kht., Budapest. Kézirat.

Potapchuk, W.R. (1995) Public Participation. - National Civic Review. Tavasz. Public Participation Manual Canadian Urban Institute.

Selman, P. (2001) Social Capital, Sustainability and Environmental Planning. - Planning Theory and Practice. 1. 13-30. o.

Stephenson, R. (2000) Technically Speaking: Planning Theory and the Role of Information in Making Planning Policy. - Planning Theory and Practice. 1. 95-110. o.

Szelényi I. (1973) Bevezetỏ tanulmány. - Szelényi I. (szerk.) Városszociológia. KJK, Budapest. 7-38. o.

Taylor, T. (1999) Town planning 'social' nor just 'physical'? - Greed, C.H. (ed.) Social Town Planning. Routledge, London-New York. 29-43. o.

Thompson, R. (2000) RE-definig planning: The roles of theory and Practice. - Planning Theory and Practice. 1. 125-134. o. 


\section{PARTICIPATION IN URBAN PLANNING}

\section{GÁBOR CSANÁDI - ADRIENNE CSIZMADY - LEA KŐSZEGHY}

The city development is determined partly by spontaneous processes generated by the capitalist market economy and also by urban policy and planning. As a consequence of these processes some groups of the society gain advantages while others suffer damages. When we try to analyse sociologically the urban policy and planning our focus is not on realised physical results, but on the system of explicit or hidden social interests, power relations and conflicts. (How it is related to external interests and power structures, how much it is capable of autonomous it functioning and representing its own ethos, when and how much it serves or is exposed for the stronger power structures around it.) In this study we start to unfold this very complex issue - for the sake of simplicity called: the sociology of urban planning - with the research of publicity and public participation. 